\title{
Planting the Character of Islamic Education During The Demak Kingdom and Its Relevance Today
}

\author{
Muhammad Ilyas \\ Universitas Islam Negeri (UIN) Sunan Ampel \\ Jl. Ahmad Yani No.117, Surabaya, East Java, Indonesia \\ muhammedelyaz550@gmail.com
}

\begin{abstract}
In the concept of Islamic education, several kinds of ideas have been listed in an education. In Islam, it does not forget a history where the teachings derived from the knowledge come. Especially in Java's land, a long Demak kingdom has stood and proved by its historical relics. Whit the concept of Islamic education, no other Demak kingdom must have its idea of Islamic education in Islamic upbringing in his time. This research was conducted quantitatively, the type of literature research. It will explore the literature related to Islamic education during the Demak kingdom by using the research model for the study of Islam history at the time of the Demak Kingdom, The aim of this study to see the model of education that applied at that time can develop Islam rapidly which still no communication like today. Research of result is the method used during the time of Demak kingdom was the lecture method, inserts, demonstrations and experiments and observational study using a cultural approach.
\end{abstract}

Dalam konsep pendidikan islam ini ada beberapa macam konsep yang sudah tertera dalam sebuah pendidikan. Di dalam Islam tidak melupakan sebuah sejarah dimana ajaran yang bersumber dari pendidikan itu berasal. Khususnya di dalam tanah Jawa ini telah berdiri Kerajaan Demak yang sekian lama telah telah berdiri dan terbukti oleh peninggalan-peninggalan sejarahnya. Dalam konsep pendidikan Islam tiada lain kerajaan Demak pasti mempunyai konsep pendidikan Islam tersendiri di dalam menyemerakkan agam islam di masanya. Pada masa kerajaan Demak ada beberapa metode pendidikan Islam yang dipakai seperti memakai cara mau'idah, ta'lim, 'Ibrah, dan lain sebagainya. Di dalam memakai beberapa metode tersebut dalam artikel ini dengan menganalisa beberpa langkah yang dilakukan oleh walisongo didalam mendidik masyakarakat pribumi. Tidak hanya menggunakan metode yang telah disebutkan, tapi juga ada istilah badal yang dimana badal ini merupakan sebuah guru yang berfungsi mengajari seorang murid tentang ilmu pengetahuan dan ajaran isalm. Badal ini juga bertugas sebagai guru yang dimana juga bertugas mendidik para masyarakat pribumi yang ingin mengetahui karakter dan tatakrama tentang keislaman

Keywords: Islamic Education, Islamic Culture and the Demak Kingdom.

Received: June 1, 2020; Revised: December 23, 2020; Accepted: December 29, 2020 


\section{INTRODUCTION}

Education is essential to life. When seeking sources related to education, especially Islamic education can dig from verses of the Qur'an or Hadith. Neither of these sources can be taken from wisdom, or a user needs to be applied to oneself or others. Islamic education is essentially a coaching effort and the development of human potential. The purpose of its presence in this world as a servant of God and the Caliphate God is achieved as best as possible. The potential in question includes physical and spiritual potential such as common sense, feeling, will, and other spiritual aspects (Suriadi Samsuri, Mursidin, 2018).

Education is an activity that educates oneself or others to provide guidance or invite participation in the right direction and relevant. In a community of kingdom spheres, there is often a scientific study discussing the religious or other general sciences to train and hone the mind, especially a personified character.

Indeed, in one of the educational objectives, there is no other form of character, reason, etc. Because with the right name, it will bring out the attitude of a good manners personality. Then, if the surface has become profitable, it is a step to process thinking so that how students or learners in education to be a smart child with behaviour and think clearly. So the purpose of education is not to find a place of good education and quality if the results and process are still not well organized.

But in the education world in the present day education becomes a trend to find a place where knowledge is suitable and best for himself or as a parent to see his son the best education place. By entering a quality education than his desire is no other to make a qualified student compete to be a diligent child, discipline, morale, and learning can also compete in the workforce and others (Ikhwan, 2018).

In competition looking for the best education, in general, is with the goal later if the end can compete in the workforce and do not miss the times' progress. Such as looking for state-based education. Because indeed, the prior knowledge is that there is no more educating the nation to be a good character with a character or a right attitude will advance the government and his country.

In this global era, many parents still do not understand the essence of an excellent educational purpose. In this way, there are still many people in this country for a long time in education, but is only lacking in having a right attitude and character like many of Cialis who abuses his position to do less ethical actions because the average person who has a high portion does not occupy a short education but very long in education.

As a citizen of Indonesia who loves their country who has a life of patriotism and nationalism, then will not forget the history that has been engraved in the past ago to be taken a lesson so that the nation is now more progress than the countries previously. Before the Republic of Indonesia was formed in the archipelago, Earth already has a civilization so great.

From the civilization that advanced in the old, there are several kingdoms on Earth archipelago. Not only written, but there have been many relics of the empire until now, there is a Hindu kingdom and also some of the Islamic empires (Endraswara, 2010). With these relics, there will be more robust evidence that civilization progressed at that time. 
In a kingdom, especially the Islamic empire must in its expansion step not bedone by warfare alone, but also certainly done by teaching the values of religious, humanitarian, personality, and others. Therefore, the steps can be done by organizing an education. Education in its time with the present will have an exact similarity, but indeed have the same purpose and implementation to spread the mind and the science.

Several previous studies have shown how Islamic education was during the Demak kingdom because, in the Demak kingdom's success, there was a lot of support made by Walisongo like Sunan Ampel. As Susmihara's opinion, with the research title "Islamic education in the period of the Islamic empire in the archipelago" which concluded that the process of Islamic education in the Islamic kingdoms of the archipelago received significant attention from the kings or sultans who ruled the Islamic kingdoms at that time, this is proven by the emergence of Islamic educational institutions and places of worship that have had a positive influence on the advancement of Islamic community education (Susmihara, 2018).

Muhammad Sabaruddin's research, which discusses "Islamic education patterns and policies in the early years and before independence", said the background for the emergence of Islamic education in Indonesia in the past was due to the colonialist pressure to limit religious movements in the field of education, in addition to the emergence of movements. Renewal of the religious thinking of Islamic leaders at that time, Islamic education which in this case can be represented by dayah education, surau, and pesantren are believed to be the oldest education in Indonesia (Sabarudin, 2015).

According to Umma Farida in her research entitled "Islamization in Demak Century XV M: Dynamic Collaboration of Ulama Umara in Islamic Da'wah in Demak" argues that the method of developing and broadcasting Islam adopted by umara ulama during the preaching process in the past promotes wisdom, brings people closer and rulers directly by showing the goodness of Islamic teachings (Farida, 2015a).

Agus Susilo's opinion in his research entitled "The Role of Raden Fatah in the Islamization of the Sultanate of Demak in 1478-1518" states that the function of the Great Mosque of Demak is essential in influencing the spread of Islam. Sunan Kalijaga and other walisongo spread Islam with the cultural approach of wayang kulit and gamelan arts modified in Islam. Raden Fatah as the Sultan of Demak carried out attacks in several regions in Java while simultaneously Islamizing the people peacefully. Demak also fought against the Portuguese in Malacca and stemmed the influence of Christianization by the Portuguese (Susilo \& Wulansari, 2019).

And Dewi Evi Anita's research with the theme "Walisongo: Islamizing the Land of Java, in her study revealed that the process of Islamization that took place in the archipelago was basically within the framework of the acculturation process as Islam is spread in the archipelago, including the Peninsula and Brunei as normative principles in addition to aspects of art and culture. The guardians tried to develop Javanese culture. Walisongo in the development of Javanese culture has contributed significantly to education and teaching and skills and cultural aspects in general (Anita, 2016).

Safari's opinion in "The role of the Islamic Kingdom in the development of education in Indonesia" is that the Islamic education system in the previous kingdom era has grown and developed along with the development of Islam in the archipelago, formerly centred in mosques, surau, langgar, or pesantren. Initially, these places 
doubled as places of worship and centres for studying religious sciences, including education (Safe, 2015a).

In this way, the authors will discuss how the Islamic education in the Demak kingdom, because during the Demak kingdom, is the first Islamic Kingdom that brings Islam's progress and glory in the future about the social and other economic aspects. Therefore, the authors will slightly analyze how the Demak kingdom steps to carry out an Islamic education and apply Islamic knowledge in the Demak Kingdom if in contextualized with this global era (Purwowidodo, 2016).

Therefore, here a little will analyze how the Demak Kingdom in Java Island does Islamic education. This KingdomKingdom was the first Kingdom of Java that its Islamization to exit the island of Borneo. By this will be a bit of a break down how Demak Kingdom measures manage Islamic education.

\section{METHOD}

This research was conducted quantitatively, the type of literature research, namely research that seeks to obtain data using literature sources on Islamic education during the Demak Kingdom era. Sources of data that are the centre of this research are collected through variable data which relies on the writings, thoughts and opinions of figures and experts who discuss Islamic education during the Demak Kingdom era about its current application. The quantitative data collected through the literature were analyzed using the quantitative descriptive analysis to see the aspects of Islamic education during the Demak Kingdom era and its current application. Processing and analysing data through compiling, categorizing data, looking for the content of various data obtained from the writings, thoughts and opinions of figures and experts to get their meaning.

\section{RESULT AND DISCUSSION}

\section{A Brief History of Demak kingdom}

Historians agree that the spread of Islam in Java is the Wali Songo. They did not only rule on religious grounds, but also in government and politics. It is often aking as if it were only valid asking if he had been acknowledged and endowed by Wali Songo. In the shutter, the influence of Indonesian society in the past until now can not escape from government alone but with the impact of religious figures or scholars'. In this influence, one of them is with the Islamic education applied in Indonesian society (Muhammad, 2010).

Demak was the first Islamic sultanate in the island of Java. The Sultanate of Demak was founded by Raden Fatah, whose lineage was from Prabu Brawijaya V, a Chinese Muslim woman who was awarded to Ario Damar as the Duke of Palembang. Raden Fatah grew up in Palembang, South Sumatra, Indonesia. Raden Fatah founded the Sultanate of Demak in 1478. Before the founding of the Sultanate of Demak, Java had developed several Islamic commercial towns, such as Jepara, Tuban, and Gresik, but the commercial towns were still under Majapahit rule. Demak was the territory that was awarded by Kertabumi Brawijaya V to his son, Sultan Fatah. The number of rivers and beaches in this area makes Demak capable of developing. The city's Shah 
supports it in Tuban, Gresik, Ampeldenta, and Islamic merchants, despite the abundant potential of natural resources (Susilo \& Wulansari, 2019).

With the purpose of dakwah (spread the teachings), the Walisongo also participated and then had the initiative to build mosques to facilitate the island's implementation. The mosque created was known as the Great Mosque of Demak, which is famous for one of the main pillars made of wood fragments called Soko Total (wood chips). Since the construction of the Demak Great Mosque, Islamic life has increased. The Guardians always hold a deliberation to complete the affairs of religious affairs and government affairs in the Great Mosque of Demak (Pianto \& Arif, 2017). Demak Mosque Since that time is used as a central place in discussing, communicating and dakwah.

Then the Majapahit kingdom was set back and dim from the archipelago's historical stage, then emerged a new Kingdom, namely the Sultanate of Demak, whose king was still descended from the Majapahit dynasty. The Sultan of Demak was named Raden Fatah or Sultan Syah Alam Akbar. He was Prabu Brawijaya V's son, the last king of Majapahit (Purwadi, 2010). On this occasion, Raden Fatah as the son of Majapahit who embraced Islamic feminist teaching can spread the Islamic teachings.

Demak was the first Islamic sultanate in Java. The KingdomKingdom was founded by Raden Fatah (1478-1518), Raden Fatah was a royal nobleman of Majapahit kingdom who served as the Duke of the Duchy of Bintara Demak. This sultanate was obtained from Wali Songo, consisting of nine great scholars, the earliest Islamic prosecution on Java's island. For the help of other areas that have already embraced Islam, such as Jepara, Tuban and Gresik, Raden Fatah as the Duke of Islam in Demak decided to bond with Majapahit at the time, Majapahit was in a fragile condition. With the proclamation, RadehFatah declared the independence of Demak and assumed the title of Sultan Syah Alam Akbar (Sabarudin, 2015).

After Raden Fatah was crowned king and was given the task of ruling Demak until 1518, and Demak became the centre of Islam's spreading in Javasince his reign. In the same order, only the three sultans of Demak were well known, namely Raden Fatah as the first king, the Duke of Muhammad Yunus or Pati Unus as the second king, and Sultan Trenggana, brother of Pati Unus, as the third king (1524-1546). In Raden Fatah's reign, Demak succeeded in various fields, including the expansion and defence of the KingdomKingdom, the development of Islam and it works, and the application of deliberations and cooperation between the clergy and umara (ruler). Raden Fatah's success in the expansion and defence of the KingdomKingdom can be seen when he conquered Girindra Wardhana who seized the Majapahit throne (1478) so that it could take over Majapahit role.

Then Raden Fatah also held a fight against the Portuguese, who had occupied Malacca and wanted to disrupt Demak. Raden Fatah sent an army under his son, Pati Unus or Duke Yunus or Prince Sabrang Lor (1511), although eventually failed. Raden Fatah's struggle was followed by Pati Unus, who succeeded his father in 1518. In the eld of Islamic dakwah and development, Raden Fatah tried to apply Islamic law in various aspects of life. Besides, he also built a palace and established a mosque (1479), which is famous for the Great Mosque of Demak. Wali Songo fully assisted the establishment of the mosque. 


\section{Islamic Education During Demak Kingdom}

The concept of Islamic education in the Demak Kingdom has several versions. Some are done by using culture and there with Islamic purely, but, until now, the archipelago customs are not gone thoroughly. Still, it is just that many are modified Islamically. So for more details will be slightly explained in the description below.

In the Demak Kingdom, there is work of books, namely usually 6 Bis, which is handwritten contains six books with 6 Bismillahirrahmanirrahim, by Ulama Sarkandi. Its contents are about the fundamentals of Islamic Sciences (Yusuf, 2015). Another book is Tafsir Jalalain, by Sheikh Jalaluddin al-Mahalli and Jalaluddin as Suyuthi. The Islamic Book of Islam that is still known, the Primbon, contains notes about the sciences of religion, kinds of prayers, medicines, occult, and even discourse the Guardians.

There are also books known as Suluk Sunan Bonang, Suluk SunanKalijaga, Waste Jati Sunan Geseng and others. Where the entire book was shaped and hand-written. Despite the few religious books in Demak, the Islamic religion expanded and spread throughout Indonesia with its rapidly growing territory. The Sunan and Kyai in conducting the education and broadcasting of Islam follow the system that the prophet has taught. From other things by providing good role models and real deeds. There is a special relationship between Demak kingdom and Alison go, where the role of Walisongo in the field of Da'wah is enormous.

In the period of Demak kingdom did not loose with the struggle of Walisongo while conducting Islamic education, namely Sultan Fatah and Sunan Kalijaga. As for the education process, Sunan Kalijaga is the naming of Kalijogo in the Javanese language which means keeping the river. Raden Sa'id or Raden Sahid is the name of his childhood (Hak, 2016).

Then it was interpreted that he had been on seven months period on the orders of Sunan Bonang on a river in the middle of a deserted forest as if he were guarding the river. By chance, the forest was named Kalijaga, which located in Cirebon. However, the name 'Kalijaga' is a mirror of Sunan Kalijaga'sability to maintain the flow of belief in society. It does not demonstrate an antipathy against all traditions or thoughts that are not by Islam, but rather wise and tolerant of the belief rules. Thus, Sunan Kalijaga is the only guardian who understands and deepens the flow of trust in society (Farida, 2015b).

Then, when finished through Sunan Bonang's mandate, Sunan Kalijaga returned to the original area in Cirebon after some time Sunan Kalihaja's education can be received well by the community. Then, with the news's accepted education until the Government heard it of Demak with this Sunan Kalijaga was asked to cooperate in developing Islamic teachings. Thus, it also helps the education process of Islamic religion in the Java area to exit Java.

Sunan Kalijaga has another way of preaching, which is the same as the other of Sunan Kalijga also has its charisma among the other guardians. The way to preach very flexible Javanese people who still many old beliefs are not opposed to the customs. He approached the public subtly, even in dressing, he did not wear robes, so the people did not feel haunted and willing to accept his return with pleasure. Clothes worn daily are traditional Javanese clothes that are designed and self-perfected in an Islamic fashion. The social approach uses the people who are made to be happy, and they will 
be taken to receive Islam and draw closer to the guardians. Then they were given a real understanding of Islam and were encouraged to dispose of customs contrary to the religion of Islam. The art of the people in Gamelan, Gendhing and Tembang-Tembang and Wayang are utilized to preach (Solikin et al., 2013).

Later with Walisongo, Raden Fatah established the Great Mosque of Demak. In this case, Sunan Kalijaga was appointed as the architect of mosque development. During the Islamization process in Demak, the mosque became a strategic place to develop the Islamic community. In addition to the ritual place, the mosque also becomes a centre for the Strategy, action planning in spreading Islam in the middle of community life.

In the Islamic, Kingdom has various ways when carrying out his education that isso inherent to the present. The Kingdom of the Demak is classified as the firs the Islamic Kingdom is in this Javanese and some models of education, among others: The first, lecture or direct advice. This method is the most widely used and prevalent. The studies are useful in the gathering places of Muslims such as mosques or muscle. Immediate advice can be provided, especially about the factual issues faced by the community. It is considered significant because it can solve problems directly and contextually.

The second good example. This method tends to bring out the personal charisma. With a magnificent and impressive personal appearance accentuating an excellent and praiseworthy attitude, giving birth to the attraction and the great attention of the disciples so that teachers to emulate and exemplify, the doctrine practised. The appearance of this personality was initially one of the factors that played a role in preaching Islam. It appears with a memorable figure effectively create an idol that is ultimately an example.

The third, Media art and games. Art is an effective method of Da'wah in the past. It looks like what has been done by religious advocate in Java through Wayang art. Similarly, the mawlid of Prophet Muhammad in Solo and Yogyakarta area that uses gamelan sekaten. The word sekaten is derived from the Arabic, shahadatain meaning two sentences of a creed, which is a statement of Islamic individual (Safei, 2015b).

During the time of Demak kingdom did not escape the influence of the Walisongo when the spread of Islam is where the Wali Songo has tools or media and the work that has been made by itself. The first education is done by the method of demonstration or experimentation with the use of tools or media that is the first time to implement the knowledge is done by using the yellow books by previous scholars such as the Book of Tafseer, Fiqh and so forth the second by using his own words namely such as books that are in the archipelago namely Primbon and others already mentioned above. Also, use his work like the book Suluk, every guardian or Sunan has its method of the Suluk.

Then the second education is done by way of a lecture namely the Guardians explain the materials that exist such as the books to the people who learn the time, because in the time the average society still does not fully have a book ora learning tool so can only listen carefully what is explained by his teacher called Badal is a representative of the KingdomKingdom that has a role in the community who want to learn.

This lecture method is a method inherent to the present, which is usually done during pickle-specific events on the anniversary of the big days such as inviting muballigh, Kiyai or a community gure to fill the core event. 
Then the third by way of the method of education inserts that is the way it is done by Sunan Sunan Kalijaga which when asked the community to embrace Islam is done with courtesy and not done directly and instantaneously, Sunan Kalijaga When asked the community about the teachings of Islam still use the clothes of Javanese style then when the religion of Islam by using Javanese culture and art such as puppet, Gamelan and others.

Then the fourth last education used at the time is the method of inquiry or investigators can be taken when the story of Sunan Kalijaga when given a mandate by Sunan Bonang in the form of waiting for sticks across the river fora long time. In this lesson, Sunan Kalijaga was taught how to be his face, and his mother was a disciple to his teacher and how the obligation of someone carrying out a trust.

Above, it has been exposed as a model for the Islamic State of Demak kingdom during its time. Then the education of the Demak kingdom that can be conjugated and attached to the first fuse is the discourse method that the above has been offended about the explanation. By way of this lecture do various forms of solicitations such as the story of example or the stories of the struggle of early scholars and the stories of the prophets that all can be taken wisdom and the right Suri.

Then in the period of Demak kingdom where the central in developing education in the Great Mosque of Demak, which at that time was implemented by mutual transfer of the science of the school. This model is also mushily attached until now. The first usually in the village-the village has a general study that each week is held by local Ustadz-Ustadz, the second in the Hut Cabin in learning and teaching it when the general tasks and other studies are also performed in the mosque or Mushalla. This mosque is generally a place of worship, but indeed, since the development of education has been done in the mosque in the Medina.

\section{CONCLUSION}

In the history of Islam will not be loose in expanding history of how his first origins began. In Java, Demak Kingdom started to disseminate the expansion of Islamic teachings. In spreading the teaching of science, it will not be separated from educational problems. Then the Islamic education in the time of the Demak Kingdom is a demonstration or experimentation method, lectures, inserts, and investigators. With several ways, this Demak kingdom can increase until the island of Java. While developing his education was also not separated from building mosques in terms of building and education because, at that time, the Great Mosque of Demak was a central place in drawing science.

\section{REFERENCES}

[1] Anita, D. E. (2016). Walisongo: Mengislamkan Tanah Jawa (Suatu Kajian Pustaka). Wahana Akademika: Jurnal Studi Islam dan Sosial, 1(2), 243-266.

[2] Assegaf, A. R. (2011). Filsafat Pendidikan Islam. Jakarta: Raja Grasindo Persada.

[3] Endraswara, S. (2010). Falsafah Hidup Jawa. Yogyakarta: Cakrawala.

[4] Farida, U. (2015a). Islamisasi di Demak Abad XV M : Kolaborasi Dinamis UlamaUmara dalam Dakwah Islam di Demak. At-Tabsyir: Jurnal Komunikasi Penyiaran 
Islam, 3(2), 299-318. Diambil dari journal.stainkudus.ac.id/index.php/komunikasi/article/.../1485

[5] Farida, U. (2015b). Islamisasi di Demak Abad XV M: Kolaborasi Dinamis UlamaUmara dalam Dakwah Islam di Demak. ADDIN: Media Dialektika Ilmu Islam, $3(2), 302$.

[6] Fikri, M. (2011). Konsep Pendidikan Islam; Pendekatan Metode Pengajaran. Jurnal Islam Futura, 11(1), 118.

[7] Hak, N. (2016). Rekonstruksi Historiogra Islamisasi Dan Penggalian Nilai-Nilai Ajaran Sunan Kalijaga. Jurnal Analisis, 16(1), 70.

[8] Harahap, N. S. (2014). Penelitian Kepustakaan. jurnal Iqra, 8(1), 70. https://doi.org/http://dx.doi.org/10.30829/iqra.v8il.65

[9] Ikhwan, A. (2018). Sistem Kepemimpinan Islami: Instrumen Inti Pengambil Keputusan pada Lembaga Pendidikan Islam. Istawa: Jurnal Pendidikan Islam, 3(2), 111-154. https://doi.org/10.24269/ijpi.v3i2.1503

[10] Mardeli. (2011). Konsep al-Qur'an Tentang Metode Pendidikan Islam. Jurnal Tadib, 16(1), 3 .

[11] Muhammad. (2010). Nahdhatul Ulama dan Perubahan Budaya Politik di Indonesia. el-Harakah, 12(1), 57-65.

[12] Pianto, \& Arif, H. (2017). Keraton Demak Bintoro Membangun Tradisi Islam Maritim di Nusantara. Jurnal Sosiohumaniora, 3(1), 18-26.

[13] Purwadi. (2010). The History of Javanese Kings- Sejarah Raja-raja Jawa. Jakarta: Ragam Media.

[14] Purwowidodo, A. (2016). Dialectics of Educational Technology and Reposition Islamic Education (Pai) Teacher'S Role in Globalization Era. Epistemé: Jurnal Pengembangan Ilmu Keislaman, 11(2), 137-154. https://doi.org/10.21274/epis.2016.11.2.311-338

[15] Sabarudin, M. (2015). Pola dan Kebijakan Pendidikan Islam Masa Awal dan Sebelum Kemerdekaan. Jurnal Tarbiya, 1(1), 1-17.

[16] Safei. (2015a). Peranan Kerajaan Islam dalam Perkembangan Pendidikan di Indonesia. Auladuna, 2(2), 301-308.

[17] Safei. (2015b). Peranan Kerajaan Islam dalam Perkembangan Pendidikan di Indonesia. Jurnal Auladuna, 2(2), 301-308.

[18] Solikin, M., S., \& Wakidi. (2013). Metode Dakwah Sunan Kalijaga Dalam Proses Islamisasi di Jawa. PESAGI (Jurnal Pendidikan dan Penelitian Sejarah), 1(2), 113.

[19] Supardi, D., Ghofar, A., \& Nuryadien, M. (2015). Konsep Pendidikan Moral Imam Al-Ghazali Dan Relevansinya dengan Pendidikan Agama Islam di Indonesia. Jurnal Al-Tarbawi Al-Haditsah, 1(2), 24.

[20] Suriadi Samsuri, Mursidin, M. (2018). Character Education Based on Gender Justice in The Islamic Perspective. Al-Hayat: Journal of Islamic Education, 2(2), 202-212. from http://alhayat.or.id/index.php/alhayat/article/view/26

[21] Susilo, A., \& Wulansari, R. (2019). Peran Raden Fatah Dalam Islamisasi di 
Kesultanan Demak. Jurnal Tamaddun: Kebudayaan dan Sastra Islam, 19(1), 7083.

[22] Susmihara. (2018). Pendidikan Islam Masa Kerajaan Islam di Nusantara. Jurnal Rihlah, 06(01), 13-32.

[23] Tang, M. (2018). Kajian Religius-Historis Pendidikan Islam di Indonesia. Jurnal El-Banat: Pemikiran dan Pendidikan Islam, 8(1), 57.

[24] Yusuf, M. Y. (2015). Pesantren Sains: Epistemology of Islamic Science in Teaching System. Walisongo: Jurnal Penelitian Sosial Keagamaan, 23(2), 283310. https://doi.org/10.21580/ws.23.2.280

[25] Zamzam, F. (2017). Metode Pendidikan Islam Perspektif Hadis Rasulallah saw. Jurnal Sabilarrasyad, 11(2), 72. 